\title{
Biodiesel Production from Unrefined Krating (Calophyllum Inophyllum) Seed Oil Using Supercritical Methanol
}

\author{
Chuenkhwan Tipachan', Tanawan Pinnarat ${ }^{2}$ \\ and Somjai Kajorncheappunngam ${ }^{\text {** }}$
}

${ }^{1}$ Department of Chemical Engineering, Faculty of Engineering, Khon Kean University, Khon Kaen 40002, Thailand

${ }^{2}$ Department of Chemical Engineering, King Mongkut's Institute of Technology, Ladkrabang, Bangkok 10520, Thailand

*Corresponding author. E-mail:ksomja@kku.ac.th

https://doi.org/10.12982/CMUJNS.2017.0023

\begin{abstract}
This study investigated the feasibility of biodiesel production from unrefined Krating (Calophyllum inophyllum) seed oil using supercritical methanol transesterification reaction. The experiments were conducted under various conditions of reaction temperature $\left(200,240,260,300\right.$, and $\left.350^{\circ} \mathrm{C}\right)$, pressure $(8$, $12,14,16$, and $18 \mathrm{MPa}$ ), and oil-to-methanol molar ratio (1:20, 1:40, and 1:60). All reactions were run at a constant reaction time of 10 minutes. Results showed that oil-to-methanol molar ratio, temperature, pressure, and their interactions significantly affected fatty acid methyl ester (FAME) yield. The highest FAME yield of $90.4 \%$ by weight was achieved at $260^{\circ} \mathrm{C}$, $16 \mathrm{MPa}$, and an oil-to-methanol molar ratio of 1:40. This study also showed a significant decrease in acid value of Krating seed oil from $29 \mathrm{mg}$ to $0.3 \mathrm{mg} \mathrm{KOH}$ per gram of oil compared to its biodiesel product. Moreover, most physical properties (kinematic viscosity, density, iodine number, flash point and water content) of our biodiesel product were comparable to the standard biodiesel EN14214.
\end{abstract}

Keywords: Biodiesel, Transesterification, Calophyllum inophyllum, Krating seed oil, Supercritical methanol

\section{INTRODUCTION}

Biodiesel is a renewable fuel that can serve as an alternative to petro-diesel. It is not only renewable and environmentally friendly, but also biodegradable (Demirbas, 2009). In the early period of biodiesel production, many edible plant oils, such as palm, soybean, sunflower, and rice bran oils, were used as raw materials, or feedstock (Georgogiannia et al., 2008; Kasim et al., 2009; Biktashev et al., 2011; Carrillo and Medina, 2011). However, as edible vegetable oils are expensive (Rizwanul Fattah et al., 2014), attention has turned to finding non-edible vegetable oils to replace them. 
This study investigated using Calophyllum inophyllum, a non-edible vegetable oil native to East Africa and abundant in Thailand, where it is known as Krating seed oil. The seeds, when dried, yield substantial amounts of oil - roughly $18 \mathrm{~kg}$ per $100 \mathrm{~kg}$ of dried seeds (Venkana and Reddy, 2009). However, the high kinematic viscosity $\left(74.5 \mathrm{~mm}^{2} / \mathrm{s}\right)$ and high acidity $(29 \mathrm{mgKOH} / \mathrm{g}$ of oil) of Krating seed oil make it unsuitable as biodiesel raw material using conventional methods.

Conventional production of biodiesel using a transesterification reaction has generally utilized a homogeneous base, such as potassium hydroxide $(\mathrm{KOH})$ or sodium hydroxide $(\mathrm{NaOH})$, as a catalyst. However, this method is unsuitable with vegetable oils containing high amounts of free fatty acid (FFA) or high acid value and water. These impurities can react with the base catalyst, resulting in a saponification reaction that lowers the yield. The reaction byproduct, or soap, causes emulsification that makes it difficult to separate the biodiesel product, the result of which is low quality biodiesel (Marulanda et al., 2010). Acid catalysts, such as sulfuric acid, have been used with high FFA raw materials. However, if there is water in the feedstock, it will consume the catalysts, which leads to low biodiesel yield (Lotero et al., 2005). Using a supercritical fluid process solves this problem. It is a non-catalytic reaction, whereby the vegetable oil reacts with supercritical alcohol to produce biodiesel. Saka and Kusdiana (2001) found that biodiesel production from rapeseed oil using supercritical methanol produced $95 \%$ methyl ester within 4 min (rapid reaction) with no side reactions or unwanted products, despite the presence of high free fatty acid (high acid value) and water in the feedstock.

This study investigated the effects of temperature, pressure, and oil-to-methanol molar ratio on the production of biodiesel. The fatty acid methyl ester (FAME) content of the resultant biodiesel was analyzed using a gas chromatography-mass spectrometer (GC-MS). The properties of the biodiesel, including viscosity, density, heating value, and acid value, were determined and compared with standard biodiesel.

\section{MATERIALS AND METHODS}

\section{Materials}

Krating seeds were collected from Khon Kaen Province, Thailand. Crude Krating seed oil was obtained by using a hydraulic pressing. Methanol (99.9\% purity) was purchased from Carlo Erba Reagent Co. (Italy).

\section{Methods}

Preparation of Krating seed oil. The kernels of dried Krating seeds were squeezed in a hydraulic press to extract oil; every one $\mathrm{kg}$ of kernels produced approximately 0.5 liters of oil. The oil was filtered with a thin cloth to separate the solid particles and residues. This study used the unrefined filtered oil, which is dark green, as the reactant to produce biodiesel. 
Production of biodiesel. The biodiesel was produced using the supercritical methanol method in an $800 \mathrm{~cm}^{3}$ high pressure stainless steel reactor, with a maximum working volume of $500 \mathrm{~cm}^{3}$ (Figure 1). The reaction conditions of temperature (from 200 to $350^{\circ} \mathrm{C}$ ), pressure $(8$ to $18 \mathrm{MPa}$ ), and oil-to-methanol molar ratios (1:20 to 1:60) were varied in 27 different combinations at a constant reaction time of $10 \mathrm{~min}$, as shown in Table 1.

Table 1. Experimental reaction conditions for producing biodiesel using supercritical methanol at a constant reaction time of $10 \mathrm{~min}$.

\begin{tabular}{cccccccc}
\hline Run & $\begin{array}{c}\text { Oil: } \\
\text { methanol } \\
(\text { molar })\end{array}$ & $\begin{array}{c}\text { Temperature } \\
\left({ }^{\circ} \mathbf{C}\right)\end{array}$ & $\begin{array}{c}\text { Pressure } \\
(\mathbf{M P a})\end{array}$ & $\begin{array}{c}\text { Run } \\
\begin{array}{c}\text { Oil: } \\
\text { methanol } \\
(\mathbf{m o l a r})\end{array}\end{array}$ & $\begin{array}{c}\text { Temperature } \\
\left({ }^{\circ} \mathbf{C}\right)\end{array}$ & $\begin{array}{c}\text { Pressure } \\
(\mathbf{M P a})\end{array}$ \\
\hline 1 & $1: 20$ & 200 & 16 & 16 & $1: 20$ & 260 & 8 \\
2 & $1: 20$ & 240 & 16 & 17 & $1: 20$ & 260 & 12 \\
3 & $1: 20$ & 260 & 16 & 18 & $1: 20$ & 260 & 14 \\
4 & $1: 20$ & 300 & 16 & 19 & $1: 20$ & 260 & 18 \\
5 & $1: 20$ & 350 & 16 & 20 & $1: 40$ & 260 & 8 \\
6 & $1: 40$ & 200 & 16 & 21 & $1: 40$ & 260 & 12 \\
7 & $1: 40$ & 240 & 16 & 22 & $1: 40$ & 260 & 14 \\
8 & $1: 40$ & 260 & 16 & 23 & $1: 40$ & 260 & 18 \\
9 & $1: 40$ & 300 & 16 & 24 & $1: 60$ & 260 & 8 \\
10 & $1: 40$ & 350 & 16 & 25 & $1: 60$ & 260 & 12 \\
11 & $1: 60$ & 200 & 16 & 26 & $1: 60$ & 260 & 14 \\
12 & $1: 60$ & 240 & 16 & 27 & $1: 60$ & 260 & 18 \\
13 & $1: 60$ & 260 & 16 & & & & \\
14 & $1: 60$ & 300 & 16 & & & & \\
15 & $1: 60$ & 350 & 16 & & & & \\
\hline
\end{tabular}

First, $100 \mathrm{~g}$ of unrefined Krating oil were mixed with liquid methanol according to the selected molar ratios. The oil-methanol mixture was then loaded into the reactor. After charging, the reactor was purged with nitrogen gas and closed. The desired reaction temperature and pressure were set on the controller. Both the reaction temperature and pressure inside the reactor can be monitored in real time on the control panel. Then the heater was switched on to start the reaction. The oil-methanol mixture was stirred at a constant rate of $250 \mathrm{rpm}$ in all experiments. The reaction time was measured from when the reactor reached the targeted temperature and pressure. After 10 minutes of reaction, the reactor was depressurized and cooled to room temperature with cold water. The obtained product was then poured into a separating funnel (for $30 \mathrm{~min}$ ) to separate the biodiesel layer from the glycerol layer. The resultant biodiesel product was loaded into a rotary evaporator at $40^{\circ} \mathrm{C}$ for $30 \mathrm{~min}$ to remove any excess un-reacted methanol. The biodiesel samples were subsequently analyzed for FAME content and other properties against standard biodiesel. 


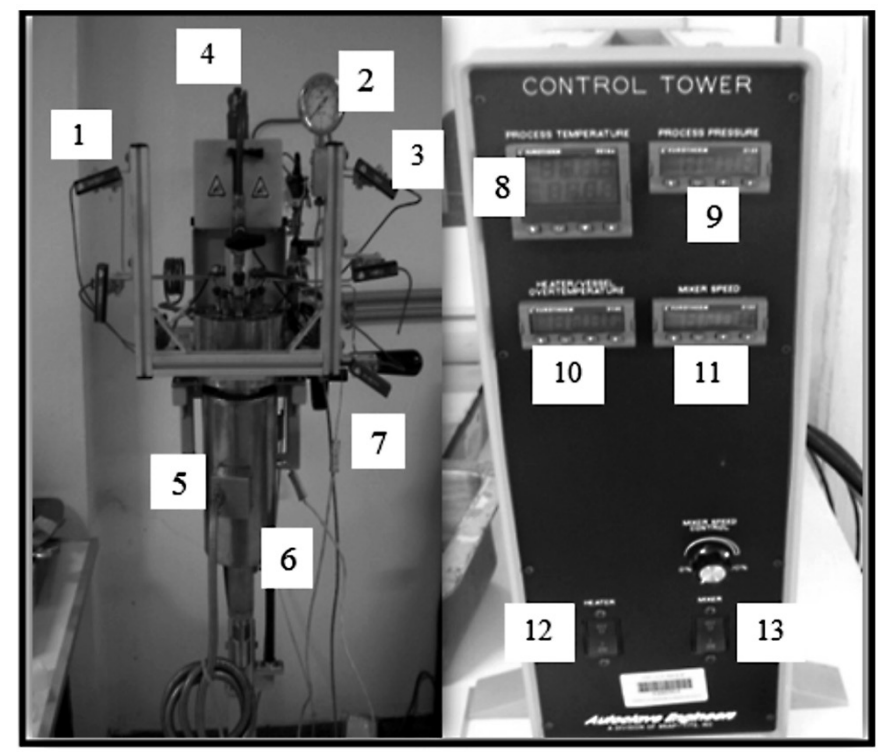

Figure 1. Experimental device for biodiesel production using supercritical methanol.

Descriptions: 1.) Gas inlet, 2.) Pressure gauge, 3.) Gas outlet, 4.) Mixing stirrer, 5.) High pressure reactor, 6.) Jacket, 7.) Thermocouple, 8.) Process temperature, 9.) Process pressure, 10.) Vessel temperature, 11.) Mixing speed, 12.) Heater ON-OFF switch, and 13.) Mixer ON-OFF switch.

Analysis. The Krating seed oil feedstock and the resulting biodiesel product were analyzed for their acid values by titration with potassium hydroxide solution based on ASTM D664, water content based on EN ISO 12937, iodine number based on EN14111, and saponification value based on AOCS official method Cd-3b-76. The heating value was analyzed according to ASTM D240, density according to ASTM D4052, kinematic viscosity according to ASTM D445, and flash point according to ASTM D93. Fatty acid methyl ester percentage (\%FAME) of biodiesel product was analyzed with a gas chromatography-mass spectrometer (GCMS-QP2610, Shimadzu, Japan) based on EN 14103.

\section{RESULTS}

\section{Effect of oil-to-methanol molar ratios}

Figure 2 shows the plot of the FAME yield of the biodiesel versus the oil-to-methanol ratio. An increase in the oil-to-methanol molar ratio from 1:20 to $1: 40$ increased the FAME yield from 84.1 to $90.4 \mathrm{wt} \%$. The FAME yield percentage dropped slightly with a further increase to 1:60. 


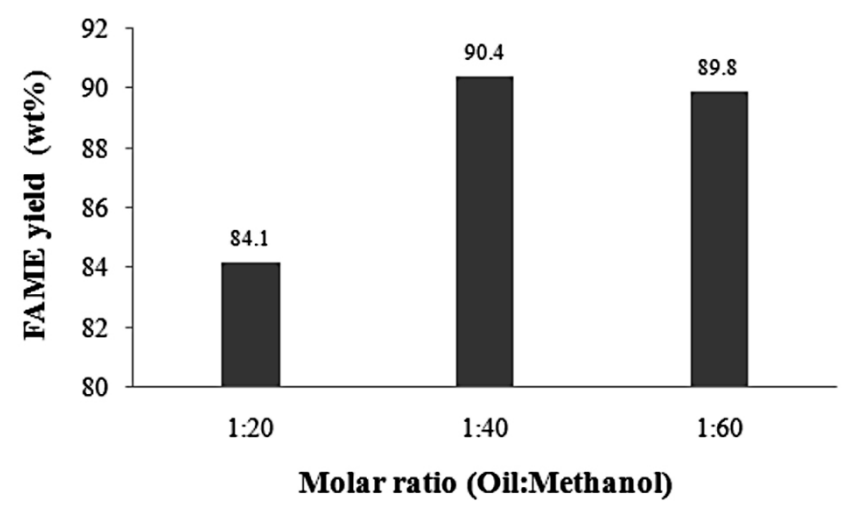

Figure 2. Correlations between FAME yield percentage and oil-to-methanol molar ratios at $260^{\circ} \mathrm{C}, 16 \mathrm{MPa}$, and $10 \mathrm{~min}$.

\section{Effect of temperature}

The FAME yield trend plotted against temperature was similar over all three oil-to-methanol molar ratios, increasing from 200 to $240^{\circ} \mathrm{C}$, then stabilizing or falling off slightly as the temperature was further increased to $350^{\circ} \mathrm{C}$ (Figure 3 ).

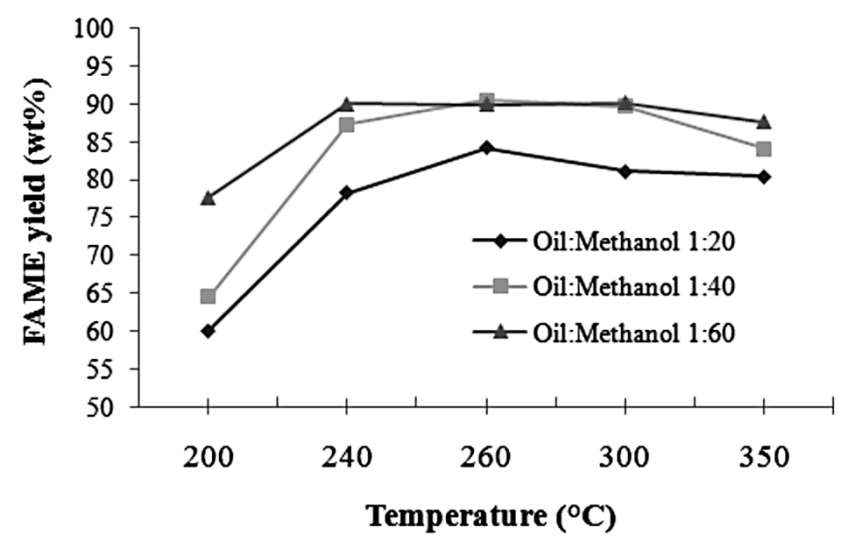

Figure 3. Correlations between FAME yield percentage and temperature at various oil-to-methanol molar ratios, all at $16 \mathrm{MPa}$ and a reaction time of 10 min.

\section{Effect of pressure}

Using a constant temperature of $260^{\circ} \mathrm{C}$, the temperature that maximized biodiesel yield, we tested five pressure levels: $8,12,14,16$, and $18 \mathrm{MPa}$. As the reaction pressure increased from 8 to $16 \mathrm{MPa}$, FAME yield steadily increased; the yield leveled off with a further increase to $18 \mathrm{MPa}$ (Figure 4). This behavior was observed in all three oil-to-methanol molar ratios. 


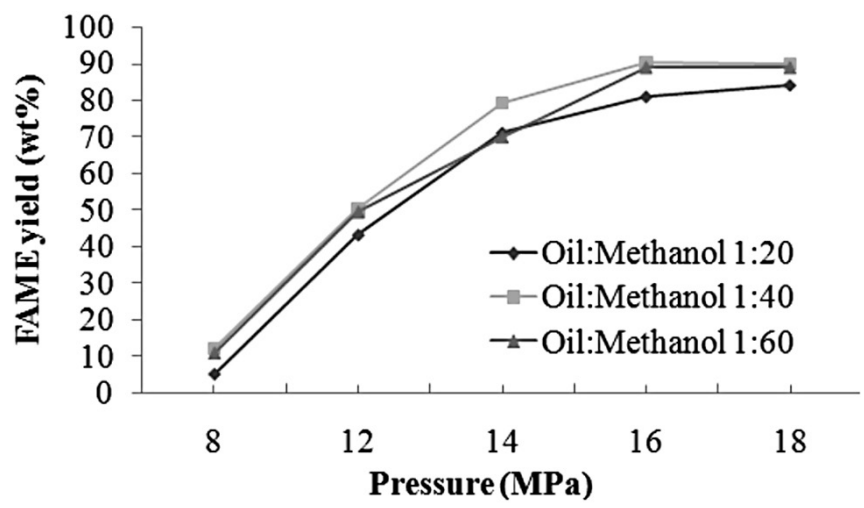

Figure 4. Correlations between FAME yield percentage and pressure at various oil-to-methanol molar ratios, all at $260^{\circ} \mathrm{C}$ and a reaction time of $10 \mathrm{~min}$.

\section{Analysis of Krating seed oil properties and its biodiesel product}

The properties of crude Krating seed oil and its biodiesel product produced at the optimal condition $\left(16 \mathrm{MPa}, 260^{\circ} \mathrm{C}\right.$, oil-to-methanol ratio $1: 40$, and $10 \mathrm{~min}$ of reaction time) were compared to biodiesel standards (Table 2). Acid value, water content, and kinematic viscosity of Krating seed oil decreased after transesterification in supercritical methanol. The highest percentage of methyl ester is 90.4 .

Table 2. Comparison of Krating seed oil, produced biodiesel, and biodiesel standard.

\begin{tabular}{|c|c|c|c|c|c|}
\hline \multirow[t]{2}{*}{ Properties } & \multirow[t]{2}{*}{$\begin{array}{l}\text { Krating } \\
\text { seed oil }\end{array}$} & \multirow[t]{2}{*}{$\begin{array}{l}\text { Produced } \\
\text { biodiesel }\end{array}$} & \multicolumn{2}{|c|}{$\begin{array}{c}\text { Biodiesel } \\
\text { standard } \\
\text { (EN 14214) }\end{array}$} & \multirow[t]{2}{*}{ Method } \\
\hline & & & Min & Max & \\
\hline Acid value (mgKOH/g) & 29 & 0.3 & - & 0.5 & ASTM D664 \\
\hline Saponification value (mgKOH/g) & 220.2 & 195.0 & - & - & AOCS Cd-3b-76 \\
\hline Iodine Number $\left(\mathrm{mgI}_{2} / 100 \mathrm{~g}\right.$ of oil) & 98.0 & 110 & - & 120 & EN 14111 \\
\hline $\begin{array}{l}\text { Kinematic Viscosity } \\
\text { (a) } 40^{\circ} \mathrm{C}\left(\mathrm{mm}^{2} / \mathrm{s}\right)\end{array}$ & 74.5 & 3.5 & 3.5 & 5.0 & ASTM D445 \\
\hline Heating value $(\mathrm{J} / \mathrm{g})$ & 37,857 & 38,453 & 36,550 & - & ASTM D240 \\
\hline Density value $@ 15^{\circ} \mathrm{C} \quad\left(\mathrm{kg} / \mathrm{m}^{3}\right)$ & 887 & 921 & 860 & 900 & ASTM D4052 \\
\hline Flash point $\left({ }^{\circ} \mathrm{C}\right)$ & - & 122 & 101 & - & ASTM D93 \\
\hline Water content (wt\%) & 2.5 & 0.05 & - & 0.05 & EN ISO12937 \\
\hline Methyl ester (wt\%) & - & 90.4 & 96.5 & - & EN14103 \\
\hline
\end{tabular}

\section{DISCUSSION}

This study investigated the potential of using inedible Krating seed oil as a feasible alternative to produce biodiesel using a supercritical methanol process. We varied three main variables: oil-to-methanol molar ratio, temperature, and pressure, to determine the optimal production condition. 
Increasing the oil-to-methanol molar ratio from 1:20 to 1:40 increased the FAME yield from 84.1 to $90.4 \mathrm{wt} \%$ (Figure 2). This phenomenon can be explained by the fact that at a higher molar ratio, more methanol molecules could surround and interact with the molecules of Krating seed oil, thereby resulting in a better reaction. This finding is consistent with Demirbas (2002), who conducted a study on cottonseed oil transesterification using supercritical methanol and found that increasing the oil-to-methanol molar ratio from $1: 1$ to $1: 40$ at $240^{\circ} \mathrm{C}$ increased the methyl ester content from 39 to $98 \%$. Our lower yield (90.4\%) might be due to the fact that Krating seed oil has more saturated fatty acids than cotton seed oil, thereby lowering the reaction rate. However, an additional increase in the ratio to 1:60 led to a slight drop in FAME yield, as the additional methanol likely diluted the reactant, resulting in less product. Another possibility is that excess methanol beyond the optimal amount is dissolved into both the biodiesel and glycerol layers during the separation process, obstructing the separation of biodiesel from glycerol; with incomplete separation, the methyl ester percentage decreases. The optimal molar ratio of oil-to-methanol of 1:40 was in good agreement with previous research on the synthesis of biodiesel using supercritical methanol from various kinds of feedstock, such as rapeseed oil, linseed oil, castor oil, and Jatropha oil (Rathore and Madras, 2007; Varma and Madras, 2007; Kusdiana and Saka, 2001).

The temperature effect from 200 to $260^{\circ} \mathrm{C}$ tended to increase the methyl ester percentage for all oil-to-methanol molar ratios. A sharp increase in biodiesel yield was observed when the temperature increased from the subcritical temperature of $200^{\circ} \mathrm{C}$ to $240^{\circ} \mathrm{C}$, a supercritical condition; the critical temperature and pressure for methanol are $239.5^{\circ} \mathrm{C}$ and $8 \mathrm{MPa}$, respectively. At higher temperature, the molecules of the substances in this study possessed more kinetic energy, so collisions occurred more frequently, resulting in increased interaction. This is in line with Saka and Kusdiana (2001), who stated that while methanol is in the supercritical state, its capacity to dissolve is close to that of a fluid and its ability to diffuse is close to a gas, hence a better interaction. A similar trend was observed for biodiesel production using supercritical methanol from other vegetable oils, such as rapeseed oil, linseed oil, palm oil, and sunflower oil (Kusdiana and Saka, 2001; Madras et al., 2004; Rathore and Madras, 2007; Varma and Madras, 2007).

At even higher temperatures $\left(300-350^{\circ} \mathrm{C}\right)$, the produced biodiesel turned viscous and black, suggesting that thermal decomposition of FAMEs occurred. The same results were observed during the supercritical methanolysis of linseed oil, safflower oil (Imahara et al., 2008), and soybean oil (Quesada-Medina and Olivares-Carrillo, 2011) at temperatures over $300^{\circ} \mathrm{C}$.

Increasing the pressure increased in the FAME percentage in all three different oil-to-methanol molar ratios, as shown in Figure 4. This was probably due to the fact that under the supercritical condition, the viscosity of methanol is low and their diffusion coefficients are close to those of gas, enabling thorough diffusion. Methanol molecules could diffuse and penetrate well into the oil structure. With an increase in pressure, supercritical methanol became denser, with more mass for reaction to proceed, and hence higher FAME yield. The effect of reaction pressure on FAME yield followed the same trend as reaction temperature, but it was more pronounced (Figures 3 and 4). 
Almost all of the properties of the biodiesel produced from crude Krating seed oil using supercritical methanol in this study were within the biodiesel standards, except methyl ester, which showed a slightly lower value $(90.4 \mathrm{wt} \%)$ than that of standard biodiesel (96.5 wt\%) (Table 2).

Based on experimental results, This study has validated the possibility of producing biodiesel from crude Krating seed oil that possesses the characteristics required by the EN 14214 standard. The optimal condition to produce biodiesel using a supercritical methanol process was at $260^{\circ} \mathrm{C}, 16 \mathrm{MPa}, 1: 40$ oil-to-methanol ratio, and a reaction time of $10 \mathrm{~min}$; this optimum yielded methyl ester yield of $90.4 \mathrm{wt} \%$. Reaction pressure affected the methyl ester yield more than reaction temperature. Using supercritical methanol minimized the effect of Krating seed oil's high water and acid values, allowing for the production of biodiesel of acceptable quality without the need for pretreating the crude Krating seed oil.

\section{ACKNOWLEDGEMENTS}

We gratefully acknowledge the Energy Management and Conservation Office (EMCO), Faculty of Engineering, Khon Kaen University, Thailand for their financial support.

\section{REFERENCES}

Biktashev, S.A., Usmanov, R.A., Gabitov, R.R., Gazizov, R.A., Gumerov, F.R. Gabitov, F.M., Abdulagatov, I.M., Yarullin, R.S., and Yakushev, I.A. 2011. Transesterification of rapeseed and palm oils in supercritical methanol and ethanol. Biomass Bioenergy. 35: 2999-3011. https://doi.org/10.1016/j. biombioe.2011.03.038

Carrillo, P.O., and Medina, J.Q. 2011. Synthesis of biodiesel from soybean oil using supercritical methanol in a one-step catalyst-free process in batch reactor. Journal of Supercritical Fluids. 58: 378-384. https://doi.org/10.1016/j. supflu.2011.07.011

Demirbas, A. 2009. Biodiesel from waste cooking oil via base-catalytic and supercritical methanol transesterification. Energy Conversion and Management. 50: 923-927. https://doi.org/10.1016/j.enconman.2008.12.023

Demirbas, A. 2002. Biodiesel from vegetable oils via transesterification in supercritical methanol. Energy Conversion and Management. 43: 2349-2356. https://doi.org/10.1016/S0196-8904(01)00170-4

Georgogiannia, K.G., Kontominasa, M.G., Pomonisa, P.J., Avlonitisb, D., and Gergisc, V. 2008. Conventional and in situ transesterification of sunflower seed oil for the production of biodiesel. Fuel Processing Technology. 89: 503-509. https://doi.org/10.1016/j.fuproc.2007.10.004

Imahara, H., Minami, E., Hari, S., and Saka, S. 2008. Thermal stability of biodiesel in supercritical methanol. Fuel. 87: 1-6. https://doi.org/10.1016/j. fuel.2007.04.003 
Kasim, N.S., Tsai, T., Gunawan, S., and Ju, Y. 2009. Biodiesel production from rice bran oil and supercritical methanol. Bioresource Technology. 100: 2399-2403. https://doi.org/10.1016/j.biortech.2008.11.041

Kusdiana, D., and Saka, S. 2001. Kinetics of transesterification in rapeseed oil to biodiesel fuel as treated in supercritical methanol. Fuel. 80: 693-698. https://doi.org/10.1016/S0016-2361(00)00140-X

Lotero, E., Liu, Y., Lopez, D.E., Suwannakarn, K., Bruce, D.A., and Goodwin, J.G. 2005. Synthesis of biodiesel via acid catalysis. Industrial Engineering Chemistry Research. 44(14): 5353-5363. https://doi.org/10.1021/ie049157g

Madras, G., Kolluru, C., and Kumar, R. 2004. Synthesis of biodiesel in supercritical fluid. Fuel. 83: 2029-2033. https://doi.org/10.1016/j.fuel.2004.03.014

Marulanda, V.F., Anitescu, G., and Tavlarides, L.L. 2010. Biodiesel fuels through a continuous flow process of chicken fat supercritical transesterification. Energy Fuels. 24: 253-260. https://doi.org/10.1021/ef900782v

Quesada-Medina, J., and Olivares-Carrillo, P. 2011. Evidence of thermal decomposition of fatty acid methyl esters during the synthesis of biodiesel with supercritical methanol. Journal of Supercritical Fluids. 56: 56-63. https:// doi.org/10.1016/j.supflu.2010.11.016

Rathore, V., and Madras, G. 2007. Synthesis of biodiesel from edible and non-edible oils in supercritical alcohols and enzymatic synthesis in supercritical carbon dioxide. Fuel. 86: 2650-2659. https://doi.org/10.1016/j. fuel.2007.03.014

Rizwanul Fattah, I.M., Masjuki, H.H., Kalam, M.A., Wakil, M.A., Ashraful, A.M., and Shahir, S.A. 2014. Experimental investigation of performance and regulated emissions of a diesel engine with Calophyllum inophyllum biodiesel blends accompanied by oxidation inhibitors. Energy Conversion and Management. 83: 232-240. https://doi.org/10.1016/j.enconman.2014.03.069

Saka, S., and Kusdiana, D. 2001. Biodiesel fuel from rapeseed oil as prepared in supercritical methanol. Fuel. 80: 225-231. https://doi.org/10.1016/S00162361(00)00083-1

Varma, M.N., and Madras, G. 2007. Synthesis of biodiesel from castor oil and linseed oil in supercritical fluids. Industrial \& Engineering Chemistry Research. 46: 1-6. https://doi.org/10.1021/ie0607043

Venkana, B.K., and Reddy, V.C. 2009. Biodiesel production and optimization From Calophyllum inophyllumlinn oil (hone oil) - A three stage method. Bioresource Technology. 100: 5122-5125. https://doi.org/10.1016/j. biortech.2009.05.023 
